\title{
AC 2010-920: STUDENTS AS CONSULTANTS: A PROJECT COURSE COMBINING ENTREPRENEURSHIP AND GREEN TECHNOLOGY
}

\section{William Hornfeck, Lafayette College}

Professor Hornfeck earned MS and PhD degrees in Electrical Engineering from Auburn University. He earned the BS degree in Electrical Engineering from Penn State University. Hornfeck has taught at Lafayette College for twenty-two years, and has combined his interest in energy studies with international engineering education. He has led study abroad programs in Belgium and Germany. 


\title{
Students as Consultants: A Project Course Combining Entrepreneurship and Green Technology
}

\begin{abstract}
$\underline{\text { Abstract }}$
This paper describes an independent study course at an undergraduate college that immerses an interdisciplinary team of six students in a consulting role. Two professors guide the direction taken by the students, a third professor coordinates students' involvement in a related research project, and an outside "client" directs the team toward local economic development. Students come from backgrounds in engineering, social sciences, natural sciences, and the humanities. The consulting "contract" specifies the economic incentives for the work, and also steers the class toward the technological areas that present a fit for development and entrepreneurship. The region targeted for development is one where a once-healthy mining industry is in severe decline. The technology identified for entrepreneurial investment involves green-powered low-speed transportation. The paper describes the year-long progress of the team and the project goals. As the United States emerges from what some have termed the great recession, courses of the type described in this paper offer students the chance to be involved in the kind of activities that help to grow the economy.

\section{$\underline{\text { Introduction }}$}

Engineering accreditation standards have targeted the importance of students' educational experiences that go beyond the core technical competencies. That is, learning that includes critical thinking, teamwork, communication skills, and lifelong learning. Lafayette College describes itself as a liberal arts college with engineering, and the integration of these academic areas is an important element of the college's mission. This paper describes an interdisciplinary course that is structured to accomplish not only the integration of diverse educational fields but to build a practical knowledge base for entrepreneurial purposes. $^{1,2}$

The framework of this and other Technology Clinic courses is:

- the recruitment of six undergraduate students from diverse academic divisions, i.e., engineering, natural sciences, social sciences and humanities

- a teaching team of two professors from different academic divisions

- a project sponsor from outside (or from within) the college having a problem to be solved and funding the course at an appropriate nominal rate

- a first semester aimed at building an effective consulting team, an understanding of the project goals and background studies related to the work, and the development of novel approaches to the problem solution

- delivery of a product at the conclusion of the second semester that includes a final report, formal presentation, and ideas for follow-on implementation of ideas and possible commercial applications. 


\section{$\underline{\text { Background }}$}

Lafayette College Technology Clinics are partnerships between industry/government sponsors and the academy. Organizations often need solutions to challenges they face, but may not have the managerial time or in-house resources to devote to them. The College uses these state-of-the-art problems to challenge students. The sponsor poses the problem to be solved, provides resource personnel, and helps with financial support. Teams of highly motivated students work together finding solutions for sponsors. The course encourages team members to use their diverse majors and backgrounds to find innovative solutions. Team members are encouraged to use creative methods, such as Synectics ${ }^{3}$, with emphasis on seeking new connections among seemingly unrelated ideas, and to develop the resulting concepts into practical applications. The Technology Clinic has served fifteen different sponsors over more than two decades and has involved fifteen faculty members from across the four divisions of the College.

A few practical solutions to real problems include the following:

- a floating debris harvesting device now used on several river systems;

- a prescreening methodology for a hospital seeking to relieve bottlenecks in polysomnography testing;

- a jobs creation and economic revitalization plan for a nearby borough.

\section{$\underline{\text { Course Structure }}$}

The current Technology Clinic seeks to combine engineering, liberal education, and entrepreneurship. The genesis of this course considered the economic needs of a nearby region struggling with the decline of a once-thriving slate mining industry. A regional council of governments was offered the help of a Tech Clinic team to identify business opportunities that would lead to job growth in the region. Once a team was assembled to tackle this assignment, further discussion with representatives from sponsoring boroughs advanced the notion that enterprises related to green technologies offered the best promise for growth businesses. A distinguishing feature of the current Tech Clinic projects is adaptability to evolving requirements or project direction. In this case, once green technology became a major component of jobs creation in the region, a partnership was pursued with research efforts at the College focusing on green energy technologies. By adding a third professor to the Tech Clinic project with an ongoing research program involving green transportation, the consulting team was expanded to ten members and the problem assumed a more specific set of goals. These goals involved jobs creation, technologies associated with renewable energy, and opportunities for new businesses in the targeted region. 


\section{$\underline{\text { Practical Goals }}$}

Specific entrepreneurial possibilities represent the core practical goals of the Tech Clinic. In this regard, ongoing research in green transportation being done at the College suggested that business opportunities existed in this area. More specifically: the conversion of conventional low speed vehicles to environmentally friendly vehicles that use green propulsion methods. If an entrepreneur could anticipate technological advances that interact with a critical need to move away from fossil-fuel-based transport, innovative business ventures could emerge. The Tech Clinic has embarked on a proof of concept aimed at golf courses and the fleets of low speed vehicles that are used as golf carts.

Specific engineering studies that emerge from the entrepreneurial ambitions of the clinic are to examine the practicality of various approaches to the "greening" of golf courses and their fleets of vehicles. The golf cart presents a particularly inviting target for green engineering. It is (whether electric or gasoline powered) a nonessential means of transportation used to play a game, and uses fossil fuels for propulsion. The Tech Clinic team therefore investigated alternative propulsion systems and fuels that would be environmentally benign and sustainable. These constraints led to a consideration of solar or wind power, partnered with battery power or fuel cell engines. Engineering studies involved the vehicles themselves as well as the energy needed to recharge batteries or to generate hydrogen. An overarching engineering goal is to establish the practical possibility of a sustainable enterprise that uses only green sources of energy.

Specific liberal arts aspects to the clinic involve the teamwork that allows engineering majors to appreciate and respect the core academic attributes and unique contributions of team members from the liberal arts. The requirements of a year-long project that include oral communication, written reports, formal presentations, and qualitative approaches engage the engineering and science students in those aspects of professional performance that go beyond technical aptitude. At the same time, those team members from the social sciences or humanities gain insights from engineering and science approaches to problem solving. The core technical demands of a research and development problem that lead to quantitative analyses expose the humanities or social science student to analytical skills needed by professionals in a technological society.

Students are nominated by the faculty at large and chosen to form effective teams. The faculty members focus very directly on team building exercises and act as catalysts in the process of promoting healthy and productive team interactions, and a team spirit that results in "a whole that is more than the sum of the parts." 


\section{$\underline{\text { Timelines }}$}

The Technology Clinic follows a two-semester format with the focus of the first semester being team-building, problem definition, and exploration of possible approaches. The sequence of project activities includes:

(i) Following a prior-semester call for nominations, interviews with student candidates, and selection of a six-student team, initial team building exercises begin the first semester.

(ii) As the specifics of the problem are formulated, a number of synectic exercises are conducted and these include students as well as the three faculty members.

(iii) Because the project includes an economic development component, stakeholders include local businesses and government offices. A number of formal meetings are attended by team members, and a survey of regional business owners is conducted.

(iv) Tours of the area targeted for economic development are coupled with energy studies to bolster the backgrounds of team members as green technologies are identified as being key to jobs creation. During this time, exercises involving solar energy, wind energy, and hydrogen are conducted.

(v) The first semester concludes with the preparation of a midpoint written report, a formal presentation for stakeholders describing progress to date, plans for the second semester, and the determination of student grades.

The focus of the second semester is problem solution. Midpoint discussions with sponsors and stakeholders settle on three specific goals:

(i) Identification of business development opportunities and the amelioration of barriers to the establishment of new business ventures.

(ii) The feasibility of establishing a commercial enterprise related to the conversion of existing low-speed vehicles to employ green technologies; specifically, the fleets of golf carts commonly associated with golf courses.

(iii) The conversion of propulsion systems for two golf carts, modifying one of these using a solar-charged battery system, and a second using a fuel cell stack. Data is gathered to perform energy studies and then to analyze the payback period associated with a green fleet of low-speed vehicles. 
The following activities are therefore targeted for the concluding semester of this Technology Clinic.

- acquisition of a used [Prius] battery pack

- conversion of electric cart to solar-powered cart

- analysis of end-to-end solar-powered propulsion system

- analysis of end-to-end wind-powered propulsion system

- design of fuel-cell-powered cart

- acquisition of fuel cell stack

- conversion of electric cart to fuel-cell-powered cart

- cost analyses of solar/wind/hydrogen approaches

- prepare final report

- suggestions for business start-ups and partnerships

- suggestions for enhancements to regulatory procedures

- suggestions for at least one specific business opportunity leveraging current opportunities in green technologies

- final presentation to sponsors and stakeholders

\section{Conclusion}

Technology Clinics at Lafayette College began in 1988 and have continued without interruption since that time. The first client was the Safe Harbor Water Power Corporation of Conestoga, Pennsylvania, and a "harvester" for the removal of floating debris in waterways was a successful development from this Clinic. A partial list of the diverse group of sponsors, and project outcomes, since this first Clinic, includes:

Merck Pharmaceutical Manufacturing Division, West Point, PA (1990)

Ingersoll-Rand Pump Division, Phillipsburg, NJ (1992)

Project: Solid Waste Analysis and Management Recommendations

Binney \& Smith Company, Forks Township, PA (1996)

Project: A New Look at Manufacturing Crayolas

Filtration Engineering, Portland, PA (1997)

Project: Alternative Uses of Vacuum Excavator and Design of Extension Tools

Weller Health Education Center, Easton, PA (1999)

Project: Drunk-Driving Simulator

Bachmann Publick House, Easton, PA (2003)

Project: PDA-Based, Self-Guided Tour of History Learning Center

Cities of Easton, PA, and Phillipsburg, NJ, and Delaware River Joint Toll Bridge Commission (2005)

Project: Recommendations and Proposals for Shared River Fronts 
City of Easton "Main Street Program" (2006)

Project: Analysis and Recommendations for Downtown Revitalization

West Ward Easton Neighborhood Partnership (2008)

Project: Development of an Urban Ecology Program

The Technology Clinic at Lafayette College uses teams of students and faculty members to solve practical problems of interest for sponsoring agencies or businesses. The current Tech Clinic involves six undergraduate students and two faculty members working as a consulting team over a one academic year period. The team is charged with developing ideas to promote economic development and jobs creation in a region seeking to reestablish a business/industrial base. Long-term outcomes are expected that lead to the establishment of commercially successful enterprises.

\section{Bibliography}

${ }^{[1]}$ The Lexus and the Olive Tree, Thomas L. Friedman, May, 2000, Anchor Books

${ }^{[2]}$ Hot, Flat, and Crowded: Why We Need a Green Revolution-and How It Can Renew America, Thomas L. Friedman, Farrar, Straus \& Gireaux, New York, 2008

${ }^{[3]}$ Synectics: The Development of Creative Capacity, William J. Gordon, 1988

${ }^{[4]}$ Engineering Education: Research and Development in Curriculum and Instruction, John Heywood, IEEE, 2005

${ }^{[5]}$ Accrediation Policy and Procedure Manual, 2008-2009, ABET, Inc., Baltimore, MD 